\title{
The Influence Of Financial Management Function Towards Company's Skills And Values In Indonesia's Consumption Goods Industry
}

\author{
LCA. Robin Jonathan \\ Faculty of Economic, University of 17 Agustus 1945 \\ Samarinda Jalan Ir. H. Juanda 80 Samarinda. Kalimantan Timur, 75124, Indonesia.
}

Theresia Militina

Faculty of Economic and Business, Mulawarman University, Jalan Kuaro Gn. Kelua Samarinda. Kalimantan Timur, 75119, Indonesia..

\begin{abstract}
This study aims to analyze and determine the effect of financial management functions in the form of investment decisions, funding decisions and dividend policies on profitability and corporate value in publicly listed companies within consumer goods industry in Indonesia during 2013-2015. The population of the consumer goods industry sector that went public (www.idx.co.id) was 37 issuers and examined the financial statements of 32 issuers that distributed dividends in 2013-2015. This research is a quantitative study of causality among several variables. The data used are cross section data and secondary data types in the form of financial reports published on the Indonesia Stock Exchange, literature and research from other parties. By using financial ratios related to financial management functions: investment decisions, funding decisions, dividend policy as an independent variable and profitability and firm value as the dependent variable, using path analysis assisted with the SPSS version 20 , can be seen the magnitude of influence shown by the path coefficient on each path diagram of the causal relationship between the independent variables to the dependent variable. The results showed that the functions of financial management have a significant effect on profitability. Investment decisions and profitability of companies have a positive and significant effect on firm value, while funding decisions and dividend policies have no significant effect on firm value. Proficiency does not have a significant effect in mediating the functions of financial management on firm value. But in terms of probability, it helped strengthen the influence of financial management functions on corporate value.
\end{abstract}

Keywords: Financial management functions, profitability, firm value.

\section{Research Background}

\section{INTRODUCTION}

Sukmawati Sukamulja (2017: 285) said that consumer goods sector is a sector with a second market capitalization in Indonesia after the financial sector, this sector is relatively stable from economic fluctuations because it is needed by the community. Consumer goods group shares are non-cyclical shares, meaning that they are always needed whatever the economic conditions at the time so that the demand for this product is relatively constant regardless of the price. Moreover, Indonesia has large enough population (more than 260 million people) so that the business prospects in the field of consumption products are very potential.

The development of business world today is the impact of global changes that cause organizations that are running now must pay attention to the changes that are taking place. Especially in the development of Indonesia, towards an advanced and prosperous country. The company is one of the drivers of development, the company has several functions and financial 
functions are very broad and dynamic field. This field is an important part of company activities. Resources owned by the company to be managed in addition to human resources are sources of funding, namely resources in the form of funding to support company activities which will directly affect the company's performance.

S.C. Myers, ed., dalam Richard A. Brealey / Stewart C. Myers (1991:4) found that flow of cash between capital markets and the firm's operastions. Key: 1. Cash raised by selling financial assets to investros; 2. Cash invested in the firm's operations and used to purchase real asset; 3. Cash generated by the firm's operations; $4 a$. Cash reinvested; $4 b$. Cash returned to investors; as illustrated in figure 1 below:

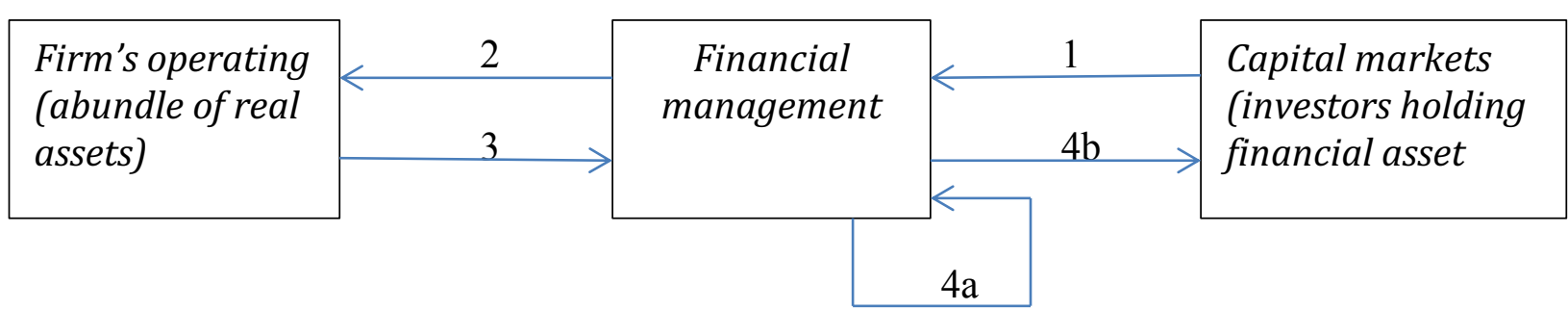

Figure 1. Financial Management Activities

According to Richard A. Brealey / Stewart C. Myers (1991:4), Sulaeman Rahman Nidar (2016:2) there are 3 decisions that ought to be made by financial manager:

1. Decisions related to the use of funds are called investment decisions,

2. Decisions related to obtaining funds are referred to as funding decisions, and

3. Decisions related to profit sharing are known as dividend policies.

The main purpose of business activities according to Buchari Alma (2001: 23), Ricky W. Griffin and Ronald J. Ebert (2006: 4) is to meet human needs and desires. From these activities, the company made profit with the intention of maximizing shareholder wealth. Normatively Eugene F. Brigham and Louis C. Gapenski (1990: 5), Alan C. Shapiro (1991: 14), Eugene F. Brigham (1992: 14), Abdul Halim (2015: 1), Sheridan Titman, et. , al. (2018: 41) said that the purpose of financial management is to maximize the welfare of the owner or to maximize the value of the company. The indicator of company value is reflected in the price of shares traded on the capital market.

\section{Problem Statement}

Does the function of financial management in the form of investment decisions, funding decisions, and dividend policies affect the ability and value of the publicly listed companies in Indonesia's consumer goods industry?

\section{Research Aims}

This research aims to identify and analyze the effect of financial management functions in the form of investment decisions, funding decisions, and dividend policies on profitability and corporate value in companies that go public within consumer good sector in Indonesia.

\section{Financial Management Function}

\section{THEORETICAL REVIEWS}

In order to achieve the objectives of financial management to maximize the value of the company, the function of financial management is basically to make some financial decisions (financial decisions) that are relevant and affect the value of the company (value of the firm). Decisions made according to Richard A. Brealey / Stewart C. Myers (1991: 4) are: a. Investment decision. b. Financing decision (funding decision). c. Dividend Policy 


\section{Investment decision}

Alan C. Shapiro (1991:1) found that: Investment decision is concered with allocating funds over time in such a way that shareholder wealth is increased. This latter task is accomplished by undertaking activities and purchasing asset that are worth more than they cost.

Investation is one of important indicators in increasing corporate's value. Researches by Murniati S, et., al. (2019), Dimas, et., al. (2013), Oktaviana, et., al. (2013), dan Putri, et., al. (2012) showed that investment decisions have positive and significant impact on firm value.

The company always aims for continuous growth, but also must pay attention to the company's ability to make a profit. The company's growth reflects the company's success. High growth reflects investment success in the past and encourages companies to re-invest in the future. Supporting factors for investing according to Hery (2017: 60) is that there is a great opportunity to benefit from investment. Companies tend to hold a portion of their income and profits for investment. The investment decision is said to be effective will be reflected in the achievement of the rate of return that in future times exceeds the initial investment value for a certain period. Thus, the higher the investment made in assets, shows the higher the growth of the company, the more increased the value of the company.

\section{Financing decision}

Alan C. Shapiro (1991: 1) says that: Involves generating funds either internally or from sources external to the firm at the lowest possible cost. This decision talks about how much debt and equity will be used. Suad Husnan and Enny Pudjiastuti (2002: 319) say that the use of debt can be justified as long as it is expected to provide additional operating profit that is greater than the interest paid. This decision is measured by the ratio of debt to total assets. This decision is said to be effective, reflected in the minimal cost of funds.

Suad Husnan and Enny Pudjiastuti (2002: 293) said that changes in the composition of the source of funds or capital structure that can maximize the value of the company or the price of shares, is the best capital structure. Modigliani, F. and Miller, MH. (1963: 433) suggested that in a perfect capital market and no taxes, capital structure does not affect the value of the company. However, in a perfect capital market and taxes, additional debt affects the value of the company. Thus Modigliani, F and Miller, MH. (1963: 433) asserted that the addition of debt would increase the value of the company, meaning that if the company owed, the value of the company would increase. The results of the study by Murniati S, et., Al. (2019), Dimas, et. al., (2013) and Putri, et., al. (2012) show that funding decisions have positive and significant impact on firm value. But the results of research Oktaviana, et., Al. (2013) shows that funding decisions negatively effect insignificant value to the firm.

\section{Dividend policy}

Alan C. Shapiro (1991: 2) found that this ultimate objective of both financial functions is to maximize the shareholder wealth. This means making financing and investment decisions that add as much value as possible to the firm. It also means that companies must manage effectively the assets under their control. Abdul Halim (2015: 3) said that in principle the dividend policy concerns the decision of what percentage of the profits earned by the company will be distributed to shareholders in the form of dividends, and what percentage will be retained in the form of retained earnings for future investment financing. Some want dividends to be distributed as much as possible, others want dividends to be distributed as small as possible, and some are of the opinion that dividend policy is irrelevant. Suad Husnan and Enny Pudjiastuti (2002: 334) indicated that an increase in dividend payments is only possible if the profits are increased. Companies cannot divide dividends that are even greater if the profits 
earned do not increase. It is not true that a company must divide all profits in the form of dividends. Profits are justified to be retained, if the funds can be invested and produce a profit rate that is greater than the cost of capital.

The purpose of dividend distribution is to improve performance and motivate stakeholders so that the value of the company increases. The results of the study by Murniati S, et., Al. (2019) shows that dividend policy has a negative and insignificant effect on firm value. Putri, et., Al. (2012) shows that dividend policy has a negative effect on campaign value. In contrast to the results of research Oktaviana, et., Al. (2013) shows that dividend policy has a positive and significant effect on firm value. This shows that the effect of dividend policy on firm value varies.

\section{Profitability}

Abdul Halim (2015: 215) said that profitability ratios are used to measure the effectiveness of companies in managing assets and equity owned to generate profits. The higher the profitability ratio, the more effective the company will manage the company's assets and equity. There are three ratios that are often used:

1. Profit margin (PM) is used to determine the extent of the company's ability to generate net profit at a certain sales level. High PM illustrates the company's ability to generate high profits at a certain level of sales.

2. Return on total assets (ROA) can be used to determine the extent to which the company's ability to generate net income based on certain asset levels. High ROA illustrates the ability of asset management to work efficiently.

3. Return on equity (ROE) can be used to determine the extent of the company's ability to generate profits based on certain share capital. This ratio is a measure of the company's profitability from the perspective of the shareholders. Nevertheless, Mamduh and Abdul Halim (2016: 81) suggested that this ratio does not take into account dividends or capital gains for shareholders. Therefore, ROE is not a true measure of shareholder return. ROE is influenced by ROA and the company's financial leverage level. Thus, ROE can be used to measure the ability of a company's equity in generating profits that are the rights of the owners of their own capital. Investors will be interested in buying shares with this profitability measure, or part of the total profitability that can be allocated to shareholders.C. Nilai Perusahaan.

In order to make the right financial decisions, it is necessary to first determine the objectives to be achieved. Suad Husnan and Enny Pudjiastuti (2002: 7) say that the purpose of financial decisions is to maximize the value of the company. The value of the company is the price that prospective buyers are willing to pay if the company is sold. For companies that issue shares in the capital market, stock prices are an indicator of company value. The higher the company's stock price, the higher the company's value, the greater the prosperity received by the company's owner. Research Murniati S, et al. in IJAFAP Volume 2 No. 1 (2019), showed that investment decisions and financing decisions have positive and significant effects on profitability and value of the firm so that the main objective of the company is to maximize the welfare of company owners by increasing the value of the firm through increasing profitability. While dividend policy has a negative and not significant effect on profitability and value of the firm directly and indirectly. Likewise with research conducted by Fajaria, et.al. (2017) in AEBMR, volume 35 (p.25-32) and MICEB (2017) as follows: 
Tabel 1. Previous Researches

\begin{tabular}{|l|l|l|l|}
\hline \multicolumn{1}{|c|}{$\begin{array}{c}\text { Author } \\
\text { Journal, Year: Pages }\end{array}$} & $\begin{array}{l}\text { Investment Decision on } \\
\text { Company's Value }\end{array}$ & $\begin{array}{c}\text { Funding Decision on } \\
\text { Company's Value }\end{array}$ & $\begin{array}{c}\text { Dividend Policies on } \\
\text { Company's Value }\end{array}$ \\
\hline $\begin{array}{l}\text { Dimas, et.al. } \\
\text { JAB, 5(1) 2013:117-124 }\end{array}$ & $\begin{array}{l}\text { The effect is positive } \\
\text { and significant }\end{array}$ & $\begin{array}{l}\text { The effect is positive } \\
\text { and significant }\end{array}$ & \\
\hline $\begin{array}{l}\text { Oktaviana, et.al. } \\
\text { MAJ, 2(2) 2013:1-7 }\end{array}$ & $\begin{array}{l}\text { The effect is positive } \\
\text { and significant }\end{array}$ & $\begin{array}{l}\text { The effect is positive } \\
\text { and significant }\end{array}$ & $\begin{array}{l}\text { The effect is positive } \\
\text { and significant }\end{array}$ \\
\hline $\begin{array}{l}\text { Putri, et.al. } \\
\text { JKAB, I(1)2012:1-23 }\end{array}$ & $\begin{array}{l}\text { The effect is positive } \\
\text { and significant }\end{array}$ & $\begin{array}{l}\text { The effect is positive } \\
\text { and significant }\end{array}$ & $\begin{array}{l}\text { The effect is negative } \\
\text { and insignificant }\end{array}$ \\
\hline $\begin{array}{l}\text { Fajaria, et.al } \\
\text { AEBMR,35,2018:25-32 }\end{array}$ & $\begin{array}{l}\text { The effect is positive } \\
\text { but insignificant }\end{array}$ & $\begin{array}{l}\text { The effect is negative } \\
\text { and insignificant }\end{array}$ & $\begin{array}{l}\text { The effect is positive } \\
\text { and significant }\end{array}$ \\
\hline
\end{tabular}

Sources: Ardina, et al. in Journal AEBMR volume 35 (p.25-32).

According to above theories, author made the following conceptual framework:

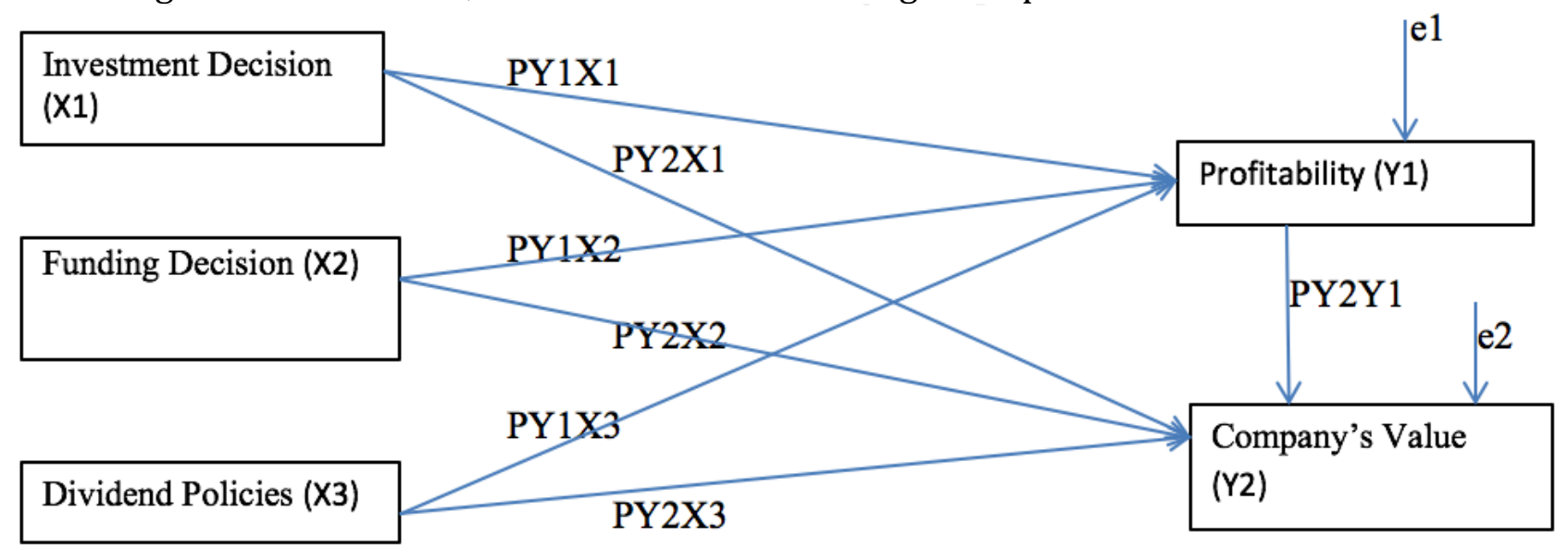

Figure 2. Conceptual Framework

\section{Hypotheses:}

1. Investment Decisions, Funding Decisions, and Dividend Policies partially have significant effect on Profitability.

2. Investment Decisions, Funding Decisions, Dividend Policy, and Profitability partially have significant effect on firm value.

3. Investment Decisions, Funding Decisions, and Dividend Policies partially have significant effect on the value of the company through Profitability.

\section{RESEARCH METHODOLOGY}

This research focuses on the Effect of Investment Decisions (X1) projected in the investment opportunity ratio measured by the ratio between retained earnings and total assets (Retained Earning / Total Assets), Funding Decisions (X2) projected in the debt ratio measured by the ratio between debt (debt) and total assets (D / A), and Dividend Policy (X3) projected in the dividend payout ratio (DPR) to Profitability (Y1) projected in the ratio of return on equity (ROE) and Company Value (Y2) projected in price Closing Stock Price.

There are 37 companies listed on the Indonesia Stock Exchange in 2013-2015 and 32 companies' financial statements have been examined and dividends have been distributed in 2013-2015. This research is a quantitative study of causality between several variables. The data used is cross section data and the type of data is secondary data.

Data Analysis is done through:

1. Descriptive statistics that describe the variables used; the independent variables are Retained Earning / Total Assets (R / A), Debt to Total Assets (D / A), and Dividend 
Payout Ratio (DPR), the dependent variable is Return on equity (ROE) and Closing Stock Price (CSP).

2. Classic assumption test:

The multiple linear regression model is used to test the linear relationship of the dependent variable and the independent variable. This model is said to be good if it fulfills normality, linearity and is free from classical assumption problems. Imam Gozali (2012) said that the most fundamental classical assumptions are tests of normality and multicollinearity. Olobatuyi (2006) added a linearity and autocorrelation test. Abram (2006) ignored the autocorrelation test if the data used were cross section data. Thus, testing the classic assumptions in this study include multicollinearity and heteroscedasticity tests. The testing process is carried out simultaneously with the multiple linear regression testing process using the SPSS version 20.0 program.

a. Test for normality by using the Kolmogorov-Smirnov approach. Data spread normally if the Asymp value. Sig. (2 tailed)> 0.05 .

b. Linearity Test using the Lagrange Multiplier (LM test) approach. The regression model is said to be linearly correct, if X2 count $=n x R 2$ (Gujarati, 2003) $>$ X2 table at $5 \%$ alpha.

c. Multicollinearity Test with Tolerance and Variance Inflation Factor (VIF) approaches. The model is said to be free of multicollinearity disturbance if the Tolerance value $>0.10$ and the VIF value $<10$.

d. Heteroscedasticity test is carried out using the White method approach. The model is said to be free from heteroscedasticity disorder if the calculated $\mathrm{X} 2$ value $<$ X 2 table at $\alpha 5 \%$.

3. Hypotheses testing; T Test, $F$ Test, and coefficient determination $\left(\mathrm{R}^{2}\right)$.

a. The $t$ test is used to test whether the independent variable partially has a significant effect on the dependent variable. Expressed significant effect if the value of $\mathrm{t}>\mathrm{t}$ table at $\alpha 5 \%$.

b. F test is used to test whether the independent variables simultaneously have a significant effect (fit) on the dependent variable. Declared significant effect if the value of Fcount> Ftable at $\alpha 5 \%$.

c. The coefficient of determination (R2) is used to assess the amount of contribution of the independent variable to the dependent variable. The greater the value of $\mathrm{R} 2$, the more the ability of the independent variable to explain the variation of changes in the dependent variable.

4. Mediation Variable Test.

To test the feasibility of mediation variables (Suliyanto, 2011: 198) the product of coefficient model (Sobel test) was used. Mediation variable test is done by testing the strength of the indirect effect of independent variables on the dependent variable through mediating variables. Mediation variables are considered feasible if the value of Zhitung> Ztable at $\alpha=5 \%$.

5. Path Analysis

Path analysis is used to determine the causal relationship between variables in order to determine the direct and indirect effects of causal variables on an effect variable (Robert D. Rutherford, in Ratlan Pardede and Renhard Manurung, 2014: 16). Steps in path analysis include:

a. Determine the path diagram based on the linear relationship paradigm. The path diagram consists of: exogenous variables X1, X2, X3 and endogenous variables Y1 and $\mathrm{Y} 2$.

b. Determine the equation:

Substructure equation $1 \mathrm{Y}_{1}=\mathrm{PY}_{1} \mathrm{X}_{1}+\mathrm{PY}_{1} \mathrm{X}_{2}+\mathrm{PY}_{1} \mathrm{X}_{3}+\mathrm{e}_{1}$ 
Substructure equation $2 \mathrm{Y}_{2}=\mathrm{PY}_{2} \mathrm{X}_{1}+\mathrm{PY}_{2} \mathrm{X}_{2}+\mathrm{PY}_{2} \mathrm{X}_{3}+\mathrm{PY}_{2} \mathrm{Y}_{1}+\mathrm{e}_{2}$

c. Analysis Steps: a. Analyse Substructure equation 1

b. Analyse Substructure equation 2

\section{Analysis}

\section{ANALYSIS AND FINDINGS}

\section{Analysis of Substructure equation 1}

a. Descriptive Statistics

According to substructure equation 1: Y1=PY1X1+PY1X2+PY1X3+e1, where Y1 = Profitability $(\mathrm{ROE}) ; \mathrm{X} 1$ = Investment Decision (R/A); X2 = Funding Decision (D/A); dan X3 = Dividend Policies (DPR); $\mathrm{P}=$ Beta Standardized; dan e1 = error. Therefore, dependent variable is $\mathrm{Y} 1=$ $\mathrm{ROE}$; independent variable is $\mathrm{X} 1=\mathrm{R} / \mathrm{A} ; \mathrm{X} 2=\mathrm{D} / \mathrm{A}$; dan X3 = DPR.

Tabel 2. Descriptive Statistics

Descriptive Statistics

\begin{tabular}{|l|c|c|c|}
\hline & Mean & Std. Deviation & N \\
\hline Y1 & 24,3025 & 21,68079 & 32 \\
\hline $\mathrm{X} 1$ &, 4539 &, 25540 & 32 \\
\hline $\mathrm{X} 2$ &, 3619 &, 22033 & 32 \\
\hline $\mathrm{X} 3$ & 31,3194 & 32,89628 & 32 \\
\hline
\end{tabular}

Source: Result of Multiple Linear Regression

\section{b. Classic Assumption Test}

The multiple linear regression model is used to test the linear relationship of the dependent variable and the independent variable. In order to check the feasibility of a model used, the following tests are used:

\section{Normality Test}

Normality Test is used to test whether standardized residuals in the regression model are normally distributed. The residual value is said to have normal distribution if the standardized residual value is mostly close to the average. Thus, the normality test here is not carried out per variable (univariated) but on the value of standardized residuals (multivariated).

The Normality Test uses the Kolmogorov-Smirnov non-parametric statistical test, obtained:

Table 3. Result of Normality Test.

One-Sample Kolmogorov-Smirnov Test.

\begin{tabular}{|lc|c|}
\hline & & Standardized Residual \\
\hline $\mathrm{N}$ & & 32 \\
\hline Normal Parametersab & Mean & $0 \mathrm{E}-7$ \\
\hline & Std. Deviation & 95038193 \\
\hline Most Extreme Differences & Absolute &, 165 \\
\hline & Positive &, 165 \\
\hline & Negative &,- 105 \\
\hline Kolmogorov-Smirnov Z & &, 933 \\
\hline Asymp. Sig. (2-tailed) & &, 349 \\
\hline
\end{tabular}

a. Test distribution is Normal

b. Calculated from data.

Source: Result of Multiple Linear Regression

Based on the above result, value of asymp.sig. (2-tailed) is $0,349>0.05$. It means data are distributed. 


\section{Linearity Test}

This Linearity Test is needed to identify which model is proved to be a linear model or not. Linearity test with the Lagrange Multiplier (LM-Test) method was carried out to measure linearity. Suliyanto (2011: 163) says that the principle of this method is to compare the calculated X2 value (nxR2) with the X2 table value with $\mathrm{df}=(\mathrm{n}, \alpha)$.

Table 4. Result of Linearity Test

Model Summarya

\begin{tabular}{|c|c|c|c|c|}
\hline Model & R & R-Square & Adjusted R_Square & Std. Error of the Estimate \\
\hline 1 & $.150^{\mathrm{a}}$ & .022 & -.082 & 18,62214914 \\
\hline
\end{tabular}

a. Predictors (Constant), X3sqr, X2sqr, X1sqr.

b. Dependent Variable: Unstandardized Residual.

Source: Result of Multiple Linear Regression

Based on table $4, \mathrm{R}^{2}$ value $=0,022$. Value of $\mathrm{X}^{2}=0,682<\mathrm{X}^{2}$ table $=44,985$, thus it can be concluded that the regression model is linear.

\section{Multicollinearity Test}

Multicollinearity Test aims to test whether in the regression model that is formed there is a high or perfect correlation between independent variables. This multicollinearity test can be done by looking at the value of TOL (Tolerance) and Variance Inflation Factor (VIF) of each independent variable on the dependent variable. If the VIF value $<10$ and TOL value $>0.10$, there are no symptoms of multicollinearity.

Table 5. Result of Multicollinearity Test

Coefficientsa

\begin{tabular}{|c|c|c|}
\hline \multicolumn{3}{|c|}{ Collinierity Statistics } \\
\hline & Tolerance & Variace Inflation Factor (VIF) \\
\hline $\mathrm{X} 1$ & ,312 & 3,210 \\
\hline $\mathrm{X} 2$ & ,304 & 3,292 \\
\hline $\mathrm{X} 3$ & ,933 & 1,072 \\
\hline
\end{tabular}

a. Dependent Variable: Y1

Based on Table 5, Tolerance value $>0.10$ and VIF $<10$. It means there are no symptoms of Multicollinearity on this regression model.

\section{Heteroscedasticity Test}

Heteroscedasticity means that there are variable variants in the regression model that are not the same (constant). If the variable variant in the regression model has the same value (constant) as expected in the regression model, it is called homoscedasticity. To test Heteroscedasticity, White Test is used by regressing all the independent variables, the free squared variable, and the multiplication (interaction) of the independent variable on the residual value of the square. If the calculated $X 2$ value $(\mathrm{n} \times \mathrm{R} 2)>$ of the $\mathrm{X} 2$ value table with $\mathrm{df}=$ $(n, \alpha)$, in the model against heteroscedasticity disorders. 
Table 6. Result of Heteroscedasticity Test

Model Summarya

\begin{tabular}{|c|c|c|c|c|}
\hline Model & R & R-Square & Adjusted R_Square & Std. Error of the Estimate \\
\hline 1 &, $757 \mathrm{a}$ &, 573 &, 399 & 754,31689 \\
\hline
\end{tabular}

a. Predictors (Constant), X3sqr, X2sqr, X1sqr, X3_X2, X2_X1, X1_X3, X3, X2, X1

b. Dependent Variable: U2

\section{Source: Result of Multiple Linear Regression}

Based on Table $6, \mathrm{R}^{2}$ value $=0,573$, Value of $\mathrm{X}^{2}=17,763<\mathrm{X}^{2}$ table $=46,194$. Therefore, it can be concluded that this regression model has no Heteroscedasticity symptopms.

\section{c. Hypotheses Test}

\section{Coefficient of Determination $\left(R^{2}\right)$.}

$\mathrm{R}^{2}$ describes the contribution of the dependent variable to the independent variable. The higher the value of $\mathrm{R} 2$, the higher the ability of the independent variable to explain variations in changes in the dependent variable.

Table 7. Coefficient of Determination $\left(R^{2}\right)$.

Model Summarya

\begin{tabular}{|c|c|c|c|c|}
\hline Model & R & R-Square & Adjusted R_Square & Std. Error of the Estimate \\
\hline 1 &, $564^{\mathrm{a}}$ &, 318 &, 245 & 18,83454 \\
\hline
\end{tabular}

a. Predictors (Constant), X3, X2, X1

b. Dependent Variable: Y1

\section{Source: Result of Multiple Linear Regression}

Table 7 shows the regression model used can explain the influence of independent variables towards dependent variables by $31,80 \%$ and the rest of $68.20 \%$ influenced by variables outside this regression model.

\section{F test}

The $\mathrm{F}$ test describes the ability of the independent variables simultaneously to explain the existence of the dependent variable. If the independent variable has a simultaneous influence on the dependent variable, the regression equation model falls into the fit criteria.

Table 8. F Test Result.

ANOVAa

\begin{tabular}{|c|c|c|c|c|c|}
\hline Model & Sum of Square & $\mathrm{df}$ & Mean Square & $\mathrm{F}$ & Sig. \\
\hline 1 Regresion & 4639,028 & 3 & 1546,343 & 4,359 & $.012^{\mathrm{b}}$ \\
\hline Residual & 9932,713 & 28 & 354,740 & & \\
\hline Total & 14571,741 & 31 & & & \\
\hline
\end{tabular}

a. Dependent Variable: Y1

b. Predictors (constant), X3, X2, X1

\section{Source: Result of Multiple Linear Regression}

Table 8 shows $F_{\text {score }} 4,359>F_{\text {table }} 2,901$ on $\alpha=0.05$. It means that the model is allowed to use (fit) in order to explain the influence of independent variables towards dependent variabes.

\section{T Test}

$\mathrm{T}$ test can be used to identify whether independent variable partially influence the dependent variable. 
Table 9. T Test Result

Coefficients

\begin{tabular}{|c|c|c|c|c|c|}
\hline \multirow{2}{*}{19,689 odel } & \multicolumn{2}{|l|}{ Unstandardized Coefficients } & Standardized Coefficient & t & Sig. \\
\cline { 2 - 4 } & B & Std Error & Beta & & \\
\hline 1 (Constant) & $-29,392$ & 19,689 & & $-1,493$ &, 147 \\
\hline X1 & 71,716 & 23,729 &, 845 & 3,022 &, 005 \\
\hline X2 & 81,639 & 27,858 &, 830 & 2,931 &, 007 \\
\hline X3 &,- 268 &, 106 &,- 407 & $-2,518$ &, 018 \\
\hline
\end{tabular}

a. Dependent Variable: Y1

Source: Result of Multiple Linear Regression

Table 9 shows that independent variable X1 and X2 partially affected Y1 positive and significantly. Variable X3 affected negative and significant towards Y1. This shows that financial management functions significantly influence the ability of consumer goods companies.

Based on the result of analysis above, obtained the following result of hypothesis 1 :

Table 10. Test of Hypotesis 1

Result of Test of Hypothesis 1.

\begin{tabular}{|c|c|c|c|c|c|c|}
\hline $\begin{array}{c}\text { Dependent } \\
\text { Variable }\end{array}$ & $\begin{array}{c}\text { Independent } \\
\text { Variable }\end{array}$ & $\mathrm{P}$ & $\mathrm{T}$ & Sig. $\alpha$ 5\% & Description & Hypothesis 1 \\
\hline $\mathrm{Y} 1$ & $\mathrm{X} 1$ &, 845 & 3,022 &, 005 & significant & Accepted \\
\hline $\mathrm{F}=4,359$ & $\mathrm{X} 2$ &, 830 & 2,931 &, 007 & significant & Accepted \\
\hline Sig. $=.012$ & $\mathrm{X} 3$ &,- 407 & $-2,518$ &, 018 & significant & Accepted \\
\hline
\end{tabular}

Source: Result of Multiple Linear Regression

\section{Analysis of Substructure equation 2}

\section{a. Descriptive Statistics}

Substructure equation 2: $\mathrm{Y} 2=\mathrm{PY} 2 \mathrm{X} 1+\mathrm{PY} 2 \mathrm{X} 2+\mathrm{PY} 2 \mathrm{X} 3+\mathrm{PY} 2 \mathrm{Y} 1+\mathrm{e} 1$, where $\mathrm{Y} 2$ = Company Value (ln Stock Price), X1 = Investment Decisions (R/A); X2 = Funding Decision (D/A); dan X3 = Dividend Policies (DPR); Y1 = Profitability (ROE); $\mathrm{P}=$ Beta Standardized; dan e2 = error. Accordingly, dependent variable is $\mathrm{Y} 2=$ stock price; Independent variables are $\mathrm{X} 1=\mathrm{R} / \mathrm{A} ; \mathrm{X} 2=$ $\mathrm{D} / \mathrm{E} ; \mathrm{X} 3$ = DPR; and Y1 = ROE.

Table 11. Descriptive Statistics

Descriptive Statistics

\begin{tabular}{|l|c|c|c|}
\hline & Mean & Std. Deviation & $\mathrm{N}$ \\
\hline $\mathrm{Y} 2$ & 8,1424 & 2,35894 & 32 \\
\hline $\mathrm{X} 1$ &, 4539 &, 25540 & 32 \\
\hline $\mathrm{X} 2$ &, 3619 & 22033 & 32 \\
\hline $\mathrm{X} 3$ & 31,3194 & 32,89628 & 32 \\
\hline $\mathrm{Y} 1$ & 24,3025 & 21,68078 & 32 \\
\hline
\end{tabular}

Source: Result of Multiple Linear Regression

\section{b. Classic Assumption Test}

The multiple linear regression model is used to test the linear relationship of the dependent variable and the independent variable. To test the feasibility of a model, we use following test:

\section{Normality Test.}

Normality Test is used to test whether standardized residuals in the regression model are normally distributed. Thus, the normality test here according to Suliyanto (2011: 69) is not 
done per variable (univariated) but on the value of standardized residuals (multivariated). Normality Test using the Kolmogorov-Smirnov non-parametric statistical test, obtained:

Table 12. Uji Normalitas dengan model Kolmogorov-Sminov. One-Sample Kolmogorov-Smirnov Test.

\begin{tabular}{|c|c|c|}
\hline & & Standardized Residual \\
\hline $\mathrm{N}$ & & 32 \\
\hline Normal Parametersab & Mean & $0 \mathrm{E}-7$ \\
\hline & Std. Deviation & ,93325653 \\
\hline Most Extreme Differences & Absolute & ,144 \\
\hline & Positive & ,144 \\
\hline & Negative &,- 105 \\
\hline Kolmogorov-Smirnov Z & & ,817 \\
\hline Asymp. Sig. (2-tailed) & & ,517 \\
\hline
\end{tabular}

a. Tast distribution is Normal

b. Calculated from data.

Source: Result of Multiple Linear Regression

Based on table above, value of asymp.sig. (2-tailed) is $0.517>0.05$. It means the data are normally distributed.

\section{Linearity Test}

This Linearity Test aims to find out which model is proved to be a linear model or not. Linearity test with the Lagrange Multiplier (LM-Test) method was carried out to measure linearity. Suliyanto (2011: 163) says that the principle of this method is to compare the calculated X2 value (nxR2) with the X2 table value with $\mathrm{df}=(\mathrm{n}, \alpha)$.

Table 13. Result of Linearity Test

Model Summarya

\begin{tabular}{|c|c|c|c|c|}
\hline Model & $\mathrm{R}$ & R-Square & Adjusted R_Square & Std. Error of the Estimate \\
\hline 1 & $.117^{\mathrm{a}}$ & .014 & -.132 & 1.58662711 \\
\hline
\end{tabular}

a. Predictors (Constant), Y1sqr, X3sqr, X2sqr, X1sqr.

b. Dependent Variable: Unstandardized Residual.

Source: Result of Multiple Linear Regression

Based on table above, $\mathrm{R}^{2}$ value $=0,014$. Score of calcultaed $\mathrm{X}^{2}=0.434<\mathrm{X}^{2}$ table $=44.985$. Hence, it can be concluded that the regression model is linear.

\section{Multicollinearity Test}

Multicollinearity Test aims to test whether in the regression model that is formed there is a high or perfect correlation between independent variables. This multicollinearity test can be done by looking at the value of TOL (Tolerance) and Variance Inflation Factor (VIF) of each independent variable on the dependent variable. If the VIF value $<10$ and TOL value $>0.10$, there are no symptoms of multicollinearity. 
Table 14. Result of Multicollinearity Test

Coefficientsa

\begin{tabular}{|lcc|}
\hline \multicolumn{3}{|c|}{ Collinierity Statistics } \\
\hline & Tolerance & Variace Inflation Factor (VIF) \\
\hline X1 &, 235 & 4,257 \\
\hline X2 &, 232 & 4,302 \\
\hline X3 &, 760 & 1,315 \\
\hline Y1 &, 682 & 1,467 \\
\hline
\end{tabular}

a. Dependent Variable: Y2

Source: Result of Multiple Linear Regression

Based on Table 14, Tolerance value $>0.10$ and VIF $<10$. It means there are no symptoms of Multicollinearity on this regression model.

\section{Heteroscedasticity Test}

Heteroscedasticity means that there are variable variants in the regression model that are not the same (constant). If the variable variant in the regression model has the same value (constant) as expected in the regression model, it is called homoscedasticity. To test Heteroscedasticity, you can use the White Test by regressing all the independent variables, the free squared variable, and the multiplication (interaction) of the independent variable on the residual value of the square. If the calculated $X 2$ value $(n \times R 2)>$ of the $X 2$ value of the table with $\mathrm{df}=(\mathrm{n}, \alpha)$, in the model against heteroscedasticity disorder.

Tabel 15. Result of Heteroscedasticity Test Model Summarya

\begin{tabular}{|c|c|c|c|c|}
\hline Model & $\mathrm{R}$ & R-Square & Adjusted R_Square & Std. Error of the Estimate \\
\hline 1 &, $497 \mathrm{a}$ &, 247 &,- 374 & 2,35971 \\
\hline
\end{tabular}

a. Predictors (Constant), X1, X2, X3, Y1, Y1sqr, X3sqr, X2sqr, X1sqr, Y1_X1, Y1_X3, Y1_X2,X2_X3, $\mathrm{X} 1 \_\mathrm{X} 2, \mathrm{X} 1 \_\mathrm{X} 3$

b. Dependent Variable: U2

\section{Source: Result of Multiple Linear Regression}

Based on Table 15, $\mathrm{R}^{2}$ value $=0,247$, Score of calculated $\mathrm{X}^{2}=7,657<\mathrm{X} 2$ table $=44.985$. Accordingly, it can be concluded that the regression model has no Heteroscedasticity symptopms.

\section{c. Hypotheses Testing}

\section{Coefficient of Determination $\left(R^{2}\right)$.}

$\mathrm{R}^{2}$ describes the contribution of the dependent variable to the independent variable. The higher the value of $\mathrm{R} 2$, the higher the ability of the independent variable to explain variations in changes in the dependent variable.

Table 16. Coefficient of Determination $\left(R^{2}\right)$. Model Summarya

\begin{tabular}{|c|c|c|c|c|}
\hline Model & R & R-Square & Adjusted R_Square & Std. Error of the Estimate \\
\hline 1 &, $775^{\mathrm{a}}$ &, 600 &, 541 & 1.59767 \\
\hline
\end{tabular}

a. Predictors (Constant), Y1, X3, X2, X1

b. Dependent Variable: Y2

Source: Result of Multiple Linear Regression 
Table 16 shows that regression model explain the impact of independent variables towards dependent variables by $60 \%$, while the rest $40 \%$ is explained by other variables outside this model

\section{F Test}

Table 17. Result of F Test

ANOVAa

\begin{tabular}{|c|c|c|c|c|c|}
\hline Model & Sum of Square & $\mathrm{df}$ & Mean Square & $\mathrm{F}$ & Sig. \\
\hline 1 Regresion & 103,584 & 4 & 25,896 & 10,145 & $.000^{\mathrm{b}}$ \\
\hline Residual & 69,919 & 27 & 2,553 & & \\
\hline Total & 172,503 & 31 & & & \\
\hline
\end{tabular}

a. Dependent Variable: Y2

b. Predictors (constant), Y1, X3, X2, X1

Source: Result of Multiple Linear Regression

Table 17 shows value of calculated $F 10,145>F_{\text {table }} 2.679$ on $\alpha=0.05$. It means that the model is allowed to use (fit) in order to explain the influence of independent variables towards dependent variabes.

\section{T Test}

Table 18. Result of T Test Coefficients

\begin{tabular}{|c|c|c|c|c|c|}
\hline \multirow{2}{*}{ Model } & \multicolumn{2}{|l|}{ Unstandardized Coefficients } & Standardized Coefficient & \multirow{2}{*}{ Sig. } & \\
\cline { 2 - 6 } & $\mathrm{B}$ & Std Error & Beta & 6,203 &, 036 \\
\hline 1 (Constant) & 3,823 & 1,735 & & 2,805 &, 009 \\
\hline $\mathrm{X} 1$ & 6,502 & 2,318 &, 704 &, 873 &, 507 \\
\hline $\mathrm{X} 2$ & 1,817 & 2,701 &, 170 &,- 870 &, 392 \\
\hline $\mathrm{X} 3$ & -.009 & .010 &,- 121 & 2,525 &, 018 \\
\hline Y1 & .040 &, 016 &, 372 & & \\
\hline
\end{tabular}

a. Dependent Variable: Y2

\section{Source: Result of Multiple Linear Regression}

Table 18 shows that independent variables X1 and Y1 partially have positive and significant impact on Y1. Variable X2 has no significant impact on Y2 and Variable X2 has negative and insignificant impact on Y2.

Based on the above result of analysis, obtained the result of hypotheses 2 as follow:

Table 19. Test of Hypothesis 2.

Hasil Pengujian Hipotesis 2.

\begin{tabular}{|c|c|c|c|c|c|c|}
\hline $\begin{array}{c}\text { Dependent } \\
\text { Variable }\end{array}$ & $\begin{array}{c}\text { Independent } \\
\text { Variable }\end{array}$ & $\mathrm{P}$ & $\mathrm{T}$ & Sig. $\alpha 5 \%$ & Description & Hypothesis 2 \\
\hline $\mathrm{Y} 2$ & $\mathrm{X} 1$ &, 704 & 2,805 &, 009 & significant & Accepted \\
\hline $\mathrm{F}=10,145$ & $\mathrm{X} 2$ &, 170 &, 873 &, 507 & insignificant & Rejected \\
\hline Sig.= $=000$ & $\mathrm{X} 3$ &,- 121 &,- 870 &, 392 & insignificant & Rejected \\
\hline $\mathrm{R}^{2}=, 600$ & $\mathrm{Y} 1$ &, 372 & 2,525 &, 018 & significant & Accepted \\
\hline
\end{tabular}

\section{Source: Result of Multiple Linear Regression}

\section{Test of Mediation variables}

Mediation or intervening variables are intermediate or mediating variables, mediating the relationship between the independent variable and the dependent variable. Mediation variable regression analysis using the Product Coefficient model developed by Sobel (1982) using the 
strength (significance) indirect variables independent of the dependent variable through mediating variables.

Table 20. Test of Hypothesis 3.

\begin{tabular}{|l|c|c|c|}
\hline Variable & Z test on $\alpha 5 \%$ & Significance & Hypothesis 3 \\
\hline $\mathrm{X} 1->\mathrm{Y} 1->\mathrm{Y} 2$ & $1,57<1.96$ & insignificant & Rejected \\
\hline $\mathrm{X} 2->\mathrm{Y} 1->\mathrm{Y} 2$ & $-0,17<1.96$ & insignificant & Rejected \\
\hline $\mathrm{X} 3->\mathrm{Y} 1->\mathrm{Y} 2$ & $-1.40<1.96$ & insignificant & Rejected \\
\hline
\end{tabular}

Source: Result of Multiple Linear Regression (Model Product of Coefficient)

The output above shows that Y1 did not succeed in mediating the relationship between variables X1, X2, and X3 against Y2. This means that the capability of publicly listed companies in the consumer goods industry has not succeeded in encouraging financial management functions in increasing the value of the company.

\section{Path coefficient dichotomy.}

The analysis above illustrates the direct effect and the indirect effect between the independent variable and the dependent variable.

Table 21. Direct, Indirect, and Total Effects.

\begin{tabular}{|l|c|c|c|}
\hline Relationship & Direct Effect & Indirect Effect & Total Effect \\
\hline $\mathrm{X} 1->\mathrm{Y} 1$ & $0,845(\mathrm{~S})$ & & \\
\hline $\mathrm{X} 2->\mathrm{Y} 1$ & $0,830(\mathrm{~S})$ & & \\
\hline $\mathrm{X} 3->\mathrm{Y} 1$ & $-0,470(\mathrm{~S})$ & & \\
\hline $\mathrm{X} 1->\mathrm{Y} 2$ & $0,704(\mathrm{~S})$ & $\mathrm{X} 1->\mathrm{Y} 1->\mathrm{Y} 2=0,31434(\mathrm{TS})$ & 1,01834 \\
\hline $\mathrm{X} 2->\mathrm{Y} 2$ & $0,170(\mathrm{TS})$ & $\mathrm{X} 2->\mathrm{Y} 1->\mathrm{Y} 2=0,30876(\mathrm{TS})$ & 0,47876 \\
\hline $\mathrm{X} 3->\mathrm{Y} 2$ & $-0,121(\mathrm{TS})$ & $\mathrm{X} 3->\mathrm{Y} 1->\mathrm{Y} 2=-0,17484(\mathrm{TS})$ & -0.29584 \\
\hline $\mathrm{Y} 1->\mathrm{Y} 2$ & $0.372(\mathrm{~S})$ & & \\
\hline
\end{tabular}

\section{Sumber: Source: Result of Multiple Linear Regression}

\section{DISCUSSIONS}

Based on the output of substructure 1 and substructure 2 equations, the path diagram can be drawn as follows:

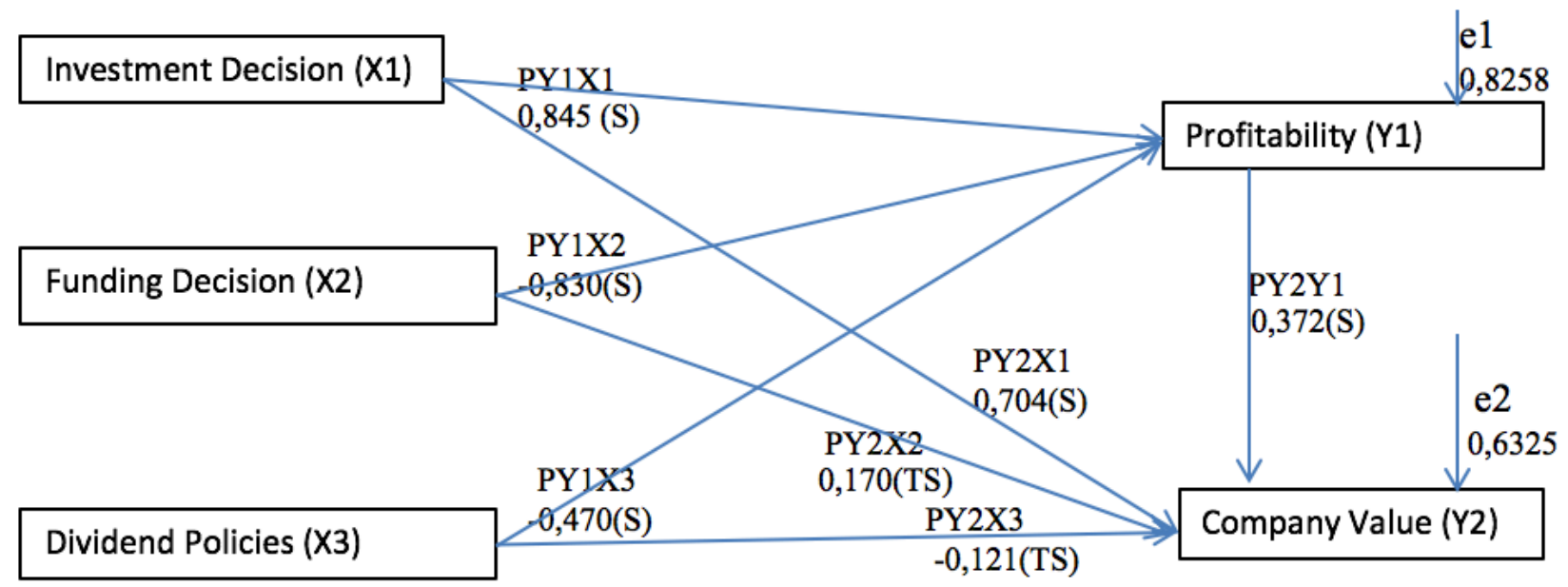

Figure 3. Path Diagram on substructure equation 1 and 2

\section{Direct Effect of Financial Management Functions on Company Profitability.}

Model: $\mathrm{Y} 1=\mathrm{P} 1 \mathrm{X} 1+\mathrm{P} 2 \mathrm{X} 2+\mathrm{P} 3 \mathrm{X} 3+\mathrm{e} 1$

$\mathrm{Y} 1=0,845 \mathrm{X} 1+0,830 \mathrm{X} 2-0,470 \mathrm{X} 3+0,8258$ 
a. Direct Effect of Investment Decisions on Company Profitability.

The output above shows that X1 (investment decision) which is projected in investment opportunities has positive and significant effect on Y1 (company capability). This means that the higher the market opportunity absorbed, the higher the company's ability to create profits. This shows that the success of investment decisions in creating a profit of $84.50 \%$ and the remaining $39.37 \%$ is related to other variables outside the investment opportunity.

\section{b. Direct Effect of Funding Decisions on Company Profitability.}

The above output shows that X2 (funding decision) which is projected in the ratio of debt and total assets has a significant effect on Y1 (corporate ability). This means that the higher the use of debt, the higher the company's ability to create profits. This shows that the success of funding decisions in creating profits by $83 \%$ and the remaining $41.23 \%$ related to other variables outside of debt.

\section{c. Direct Effect of Dividend Policy on Company Profitability.}

The above output shows that X3 (dividend policy) which is projected in the dividend payout ratio has a negative and significant effect on (Y1) the ability of the company. This means that the higher the dividend payout, the lower the company's ability to create profits. This shows that the success of dividend policy in creating a negative profit of $47 \%$ and the remaining $72.80 \%$ is related to other variables outside the dividend payout.

\section{Direct Effect of Financial Management Functions on Company Value.}

Model: Y2 = PY2X1 - PY2X2 - PY2X3 + PY2Y1 + e2

$$
\mathrm{Y} 2=0,704 \mathrm{X} 2+0,170 \mathrm{X} 2-0,121 \mathrm{X} 3+0,372 \mathrm{Y} 1+0,6325
$$

a. Direct Effect of Investment Decision on Company Value

The above output shows that X1 (investment decision) projected in investment opportunities has a positive and significant effect on Y2 (firm value). The higher the market opportunity is absorbed, the higher the value of the company. This means that investment opportunities can be used in relation to increasing company value. Therefore, the success of investment decisions in increasing company value by $70.40 \%$ and the remaining $54.40 \%$ is related to other variables outside of investment opportunities.

\section{b. Direct Effect of Funding Decision on Profitability}

The above output shows that X2 (funding decision) projected in the ratio of debt and total assets has no significant effect on Y2 (company value). The higher the use of debt, the higher the value of the company, is not significant. This means that debt can be used to increase the value of a company under certain conditions. This shows that the success of funding decisions in increasing the value of the company by $17 \%$ and the remaining $91.10 \%$ related to other variables beyond debt.

\section{c. Direct Effect of Dividend Policies on Company Value}

The above output shows that X3 (dividend policy) projected in the dividend payout ratio has negative and insignificant effect on (Y2) the value of the company. This means that the higher the dividend payout, the lower the value of the company, is not significant. This shows that the success of dividend policy in increasing the value of the company is negative $12.10 \%$ and the remaining $93.75 \%$ is related to other variables outside the dividend payout.

\section{d. Direct Effect of Profitability on Company Value}

The output above shows that Y1 (firm capability) that is projected in return on equity has a positive and significant effect on firm value. This means that the higher the company's ability to create profits, the higher the company's value. This shows that the company's success in 
creating profits amounted to $37.20 \%$ and the remaining $79.25 \%$ is related to other variables beyond return on equity.

\section{Indirect Effects of Financial Management Functions on Firm Value through Company Profitability.}

a. The Indirect Effect of Investment Decisions on Company Value through Company Profitability.

The output above shows that Y1 (firm capability) has a positive and not significant effect in mediating the effect of investment decisions on firm value. This means that the higher the company's ability to create profits, the more influential its ability to mediate investment decisions on company value. Company profitability as measured by return on equity has a positive and not significant effect in mediating the relationship of investment decisions to firm value. The magnitude of the direct effect $(\mathrm{X} 1->\mathrm{Y} 2)=0.704$ is greater than the indirect effect (X1-> Y1-> Y2) $=0.31434$, indicating that the firm's profitability does not contribute to strengthen the influence of investment decisions on firm value.

b. The effect of funding decisions on the value of the company through the company's capability.

The above output shows that Y1 (firm capability) has a positive and not significant effect in mediating the effect of funding decisions on firm value. This means that the higher the company's profitability as measured by return on equity, the more influential in mediating the relationship between funding decisions and firm value. The magnitude of the direct effect (X2$>Y 2)=0.170$ is smaller than the indirect effect $(X 2->Y 1->Y 2)=0.30876$, indicating that the existence of kemabulabaan helped strengthen the influence of funding decisions on corporate value.

c. The effect of dividend policy on company value through the company's profitability.

The above output shows that Y1 (firm capability) has a negative and not significant effect in mediating the effect of funding decisions on firm value. This means that the firm's profitability as measured by return on equity has a negative and not significant effect in mediating the relationship between funding decisions and firm value. The magnitude of the direct effect (X3$>Y 2)=-0,082$ is smaller than the indirect effect $(X 3->Y 1->Y 2)=-0.0965$, indicating that the existence of kemabulabaan also strengthens the effect of dividend policy on firm value.

\section{The effect of the total function of the company's financial management on the value of the company through the company's profitability.}

In General, profitability helped strengthen the influence of financial management functions on corporate value. This is reflected in the magnitude of the total influence of investment decisions both directly and indirectly through profitability to the value of the company of $102.83 \%>31.43 \%$. The total effect of funding decisions, both directly and indirectly through profitability to the value of the company is $47.87 \%$, greater than $30.87 \%$. The total effect of the dividend policy both directly and indirectly through profitability to the company's value of negative $29.58 \%$ is greater than negative $17.48 \%$. Thus, it can be said that profitability participated in strengthening the influence of investment decisions, funding decisions and dividend policy on corporate value. 


\section{Conclusions}

\section{CONCLUSIONS AND RECOMMENDATIONS}

1. Directly, investment decisions and funding decisions have positive and significant effect on profitability, dividend decisions have negative and significant effect on the profitability of companies.

2. Directly, investment decisions and profitability decisions have positive and significant effect on firm value, funding decisions have positive and insignificant effect on company value, and dividend policy has negative and insignificant effect on firm value.

3. Indirectly, profitability has no significant effect in mediating the influence of financial management functions: investment decisions, funding decisions and dividend policies on the value of the company

4. Overall, profitability participated in strengthening the influence of the function of financial management on the value of the company.

\section{Recommendations}

1. For further researchers, can use other variables outside this model in explaining the role of financial management functions on the ability of companies to create profits.

2. For businesses in making investment decisions, should pay more attention to the risks in investing.

\section{References}

Abrams, Jat H, (2010), Quantitative Business Valuation: A Mathematical Approach for Today's Professional, Second Edition, John Wiley \& Sons. Inc.

Alma, Buchari, (2001), Pengantar Bisnis, Edisi Revisi, Penerbit ALFABETE, Bandung.

Brealey, Richard A. Stewart C. Myers, (1991), Principles of Corporate Finance, Fourth Edition, McGraw-Hill, Inc. Singapore.

Brigham, Eugene F., (1992), Fundamentals of Financial Management, Sixth Edition, The Dryden Press, Orlondo, Florida.

Dimas, Prasetyo, Zahroh, Z.A. Devi, Farah Azizah, (2013), Pengaruh Keputusan Investasi, Keputusan Pendanaan, dan kebijakan Deviden Terhadap Nilai Perusahaan (Studi Pada Perusahaan Sektor Properti dan Real Estate yang Terdaftar di Bursa Efek Indonesia Periode 2009-2011), Jurnal Administrasi Bisnis, 5(1), 117-124.

Fajaria, Ardina Zahrah, Linda Purnamasari, Isnalita, (2017), The Effect of Investment, Funding Decision and Dividend Policy on Company Value Study on Manufacturing Company Listed in Indonesia Stock Exchang Period 2009-2013, Advances in Economics, Business and A Management Research (AEBMR), Volume 35, Mulawarman International Conference on Economics and Business (MICEB 2017), 25-31.

Ghozali, Imam, (2012), Partial Least Square: Konsep, Teknik dan Aplikasi Menggunakan Program Smart PLS 2.0M, Badan Penerbit Universitas Diponegoro, Semarang.

Halim, Abdul, (2015), Manajemen Keuangan Bisnis, Edisi Pertama, Mitra Wacana Media, Jakarta.

Hanafi, Mamduh M., dan Abdul Halim, (2016), Analisis Laporan Keuangan, Edisi Kelima, Penerbit UPP STIM YKPN, Yogyakarta.

Hery, (2017), Kajian Riset Akuntansi, Penerbit PT. Grasindo, Jakarta.

Husnan, Suad, dan Enny Pudjiastuti, (2002), Dasar-Dasar Manajemen Keuangan, Edisi Ketiga, Penerbit UPP. AMP. YKPN., Yogyakarta.

Modiglani, F. and Miller, M.H., (1963), Corporate Income Taxes and The Cost of Capital: A Correction, The American Economics, 53,433.

Murniati.S, H. Abdul Rahman Mus, H. Baharuddin Semmaila, Hj. A. Nirwana Nur, (2019) Effect of Investment Decisions, Financing Decisions and Dividend Policy on Profitability and Value of The Firm. International Journal of Acounting \& Financing in Asia Pasific, 2(1), 1-9.

Nidar, Sulaeman Rahman, (2016), Manajemen Keuangan Perusahaan Modern, Cetakan I, Penerbit Pustaka Reka Cipta, Bandung. 
Oktaviana, Tiara Sari, (2013), Pengaruh Keputusan Investasi, Keputusan Pendanaan, dan Kebijakan Dividen Terhadap Nilai Perusahaan, Management Analysis Journal, 2(2), 1-7.

Olobatuyi, Moses E, (2006), A User's Guide to Path Analysis, Lanham, Maryland: University Press of Amarica Inc.

Putri, Prihatin Ningsih, and Iin Indarti, (2012), Pengaruh Keputusan Investasi, Keputusan Pendanaan, dan Kebijakan Dividen Terhadap Nilai Perusahaan (Studi Kasus Pada Perusahaan Manufaktur yang Terdaftar di Bursa Efek Indonesia Periode 2007-2009), Jurnal Kajian Akuntansi dan Bisnis, I (1), 1-23.

Pardede Ratlan dan Renhard Manurung, (2014), Analisis Jalur (Path Analysis) Teori dan Aplikasi dalam Riset Bisnis, Penerbit Rineka Cipta, Jakarta.

Sukamulija, Sukmawati, (2017), Pengantar Pemodelan Keuangan dan Analisis Pasar Modal, Penerbit ANDI, Yogyakarta.

Suliyanto, (2011), Ekometrika Terapan: Teori dan Aplikasi dengan SPSS,Penerbit ANDI Yogyakarta.

Shapiro Alan C., (1991), Modern Corporate Finance, Machilian Publishing Company, New York.

Titman, Sheidan, Arthur J. Keown, John D. Martin, (2018), Financil Management: Priciples and Application, Thirteenth Edition, Pearson Education Limited, United Kingdom.

Van Horne, James C., (2002), Financial Management \& Policy, New Jersey, Prentice-Hall, Inc.

$\underline{w w w . i d x . c o . i d}$ 